\title{
Kajian Awal Pemanenan Siput Laut (Gastropoda) di Pantai Krakal, Yogyakarta: I. Volume Pemanenan
}

\author{
A Preliminary Study on Marine Snails Harvest (Gastropods) in Krakal Beach, \\ Yogyakarta: I. Harvested Volume
}

Felicia Zahida ${ }^{1 *}$ dan Mastok B. Sinulingga ${ }^{1}$

Fakultas Biologi, Universitas Atma Jaya Yogyakarta. Jl. Babarsari 44. Yogyakarta. 55281. Indonesia. E-mail:feliciazda@mail.uajy.ac.id *Penulis untuk korespondens.i

\begin{abstract}
A preliminary study on marine snails harvest (Gastropods) has been done in Krakal beach, Yogyakarta, during October to December 2003. Krakal beach has become an underpressure habitat since tourism industry occurred all over Indonesia. Marine snails have been harvested for over two decade but there is no study regarding the effect of this activity. This study aims to elucidate the number of species harvested, the number of each species collected, juvenil and adult, the dominant species, and hypothesize the exploitation status. Fourty species were found, 32 of these population harvested were dominated by the young. Harvest volume was about 3146 per month. These results indicate an overexploitation status.
\end{abstract}

Key words: marine snails, harvested volume, exploitation status.

Diterima: 23 Juli 2004, disetujui: 15 September 2004

\section{Pendahuluan}

Mata pencaharian sebagian penduduk daerah wisata pantai adalah penjual kerajinan. Sesuai dengan sumber daya alam yang ada, mayoritas penjualan kerajinan menggunakan bahan dasar cangkang siput laut dan kerangkerangan (Gastropoda dan Bivalvia), meskipun bahan dasar organisme lain juga ada, seperti penggunaan cangkang udang dan kepiting (Crustacea) dan tak kalah pentingnya terumbu karang (Cnidaria).

Kegiatan penjualan tersebut jelas memperkuat dan memantapkan pendapatan keluarga dan daerah wisata, namun disisi lain berbagai masalah lingkungan dan sosial menyertainya. Maraknya penjualan kerajinan yang telah dilakukan bertahun-tahun dampaknya telah dirasakan dasa warsa terakhir ini. Pengunjung pantai sekarang tidak lagi bisa merasakan kemurnian alam pantai karena lebih banyak kerusakannya dibanding dasa warsa lalu.

Kegiatan penelitian ini diharapkan dapat memberi manfaat bagi keberlangsungan aktivitas pemanenan siput laut. Aktivitas pemanenan yang dilakukan tanpa pengaturan pada gilirannya dapat merugikan masyarakat pemanen itu sendiri karena tidak adanya penghasilan tambahan akibat aktivitas yang tidak lestari.

Penelitian ini bertujuan untuk mengungkapkan beberapa permasalahan pemanenan sebagai berikut: identifikasi jenisjenis siput yang dipanen di pantai Krakal, perbandingan umur juvenil dan dewasa yang dipresentasikan dengan ukuran cangkang siput kecil dan besar yang dipanen di pantai Krakal, memperkirakan besarnya volume pemanenan perbulan. 


\section{Metode Penelitian}

\section{Lokasi dan Waktu Penelitian}

Penelitian dilakukan di pantai Krakal, Kabupaten Gunungkidul, Daerah Istimewa Yogyakarta. Pantai Krakal terletak kurang lebih $35 \mathrm{~km}$ dari kota Wonosari ke arah selatan. Penelitian dilakukan selama tiga bulan, dimulai bulan Oktober 2003 sampai bulan Desember 2003.

\section{Cara Kerja}

Sampel cangkang siput diperoleh dari penduduk pencari cangkang (pemanen). Metode sampling menggunakan whole population count. Cangkang siput diidentifikasi terutama menggunakan database foto-foto cangkang pantai selatan DIY dan diperkuat dengan menggunakan buku-buku: Bunjamin (1997), Oliver, A.P.H. (1989), dan Severn, P.F, M. Severn and R. Dyerly (1998), dilanjutkan dengan pengukuran panjang cangkang menggunakan vernier caliper dan pendataan volume panenan cangkang siput perbulan.

\section{Analisa Data}

Analisa kualitatif data pemanenan dilakukan secara deskriptif dari tabulasi silang berdasarkan data dan jawaban pemanen atas pertanyaan yang diajukan lewat kuesioner. Analisa kuantitatif panjang cangkang dianalisa perbulan dengan penentuan median sebagai faktor pembagi umur juvenil dan dewasa menggunakan SPSS ver. 10. Penentuan pemanen yang terpilih sebagai responden dilakukan dengan cara accidental sampling, yaitu pemanen yang didapati melakukan pemanenan di pantai Krakal (Nawani, 1998).

\section{Hasil dan Pembahasan}

Hasil penelitian ini ditabulasikan secara berurutan dengan pembahasan difokuskan pada hasil yang dominan dengan tekanan pada aspek konservasi.

\section{Jenis Siput yang Dipanen}

Tabel 1. menunjukkan jenis-jenis Gastropoda yang diketemukan dalam setiap pemanenan. Dalam tiga bulan pengamatan nampak bahwa ada fluktuasi jenis, pada bulan November ditemukan paling banyak jenis (32 dari 40 atau $80 \%$ ). Lebih lanjut ada 17 jenis $(42,5 \%)$ yang selalu muncul dari 40 jenis yang diketemukan dalam setiap bulan pemanenan, sementara sisanya muncul dan tidak, secara tidak teratur. Jumlah jenis sebanyak 40 tersebut menurut pengalaman relatif rendah mengingat ekplorasi sehari di pantai Wedi Ombo pada tahun 1999 dapat menghasilkan sekitar 100 jenis. Namun perlu diketahui bahwa pantai Krakal adalah pantai yang sudah menjadi tujuan wisata sejak lama, berbeda dengan pantai Wedi Ombo yang relatif masih asli. Dari kondisi yang ada tersebut bisa diduga lebih dari separuh jenis Gastropoda mempunyai populasi kecil. Hal ini dibuktikan dengan Tabel 2.

\section{Volume Pemanenan Siput}

Volume pemanenan siput dalam penelitian ini menggunakan pendekatan jumlah atau cacah individu karena banyak diantara jenis-jenis yang ada yang bernilai ekonomi relatif tinggi dijual secara bijian. Seperti dugaan semula, 33 dari 40 jenis yang ada $(82,5 \%)$ memiliki jumlah individu rendah dengan persentase masing-masing jenis kurang dari 5\%. Sementara itu tujuh jenis Gastropoda sisanya memiliki jumlah individu yang cukup besar, yaitu berturut-turut Argobuccinum pustulosum, (7,25\%), Conus lividus (7,15\%), Cypraea annettae (5,35\%), Cypraea annulus (5,33\%), Cypraea moneta (12,25\%), Pyrene testudinata $(16,95 \%)$ dan Rhinoclavis bituberculata (8,54\%). Dari tujuh jenis ini yang paling menonjol dengan persentase lebih dari 10\% adalah Cypraea moneta dan Pyrene testudinata dengan persentase $12,25 \%$ dan $16,95 \%$ sedang lima jenis sisanya kurang dari $10 \%$.

Secara visual data tujuh jenis utama dapat diperlihatkan pada Gambar 1 berikut ini. Bila di lihat kembali Tabel 1 dan Tabel 2, tampak bahwa tujuh jenis Gastropoda utama ini juga merupakan bagian dari 17 jenis 
Gastropoda yang selalu muncul dalam setiap pengambilan sampel. Melimpahnya Cypraea moneta dan Pyrene testudinaria mengingatkan pada peran siput ini pada jaman dahulu dalam budaya Indonesia (Zahida, 2002), siput ini digunakan sebagai mata uang. Pemilihan jenis untuk mata uang tentu harus dipilih dari jenis yang memiliki populasi cukup memadai bagi keperluan tersebut.

Tabel 1. Jenis Gastropoda hasil panenan di Pantai Krakal dan volume pemanenan selama tiga bulan Oktober Desember 2003 (individu)

\begin{tabular}{|c|c|c|c|c|c|}
\hline No & Jenis & Oktober & November & Desember & Total \\
\hline 1 & Argobuccinum pustulosum* & 341 & 266 & 77 & 684 \\
\hline 2 & Astrea phobia & - & - & 3 & 3 \\
\hline 3 & Bufonoria crumena & - & - & 83 & 83 \\
\hline 4 & Bursa granularis & - & - & 17 & 17 \\
\hline 5 & Cardinalia conus & - & - & 60 & 60 \\
\hline 6 & Clypeomorus traillii & 55 & 36 & - & 91 \\
\hline 7 & Conus ebraeus & 55 & 48 & 123 & 226 \\
\hline 8 & Conus capitaneus & 47 & 31 & - & 78 \\
\hline 9 & Conus lividus* & 251 & 216 & 208 & 675 \\
\hline 10 & Cypraea annettae* & 246 & 234 & 25 & 505 \\
\hline 11 & Cypraea annulus* & 204 & 234 & 66 & 504 \\
\hline 12 & Cypraea arabica & 165 & 108 & 9 & 282 \\
\hline 13 & Cypraea caput & 206 & 162 & 10 & 378 \\
\hline 14 & Cypraea corneola & 84 & 63 & 34 & 181 \\
\hline 15 & Cypraea erosa & 32 & 20 & - & 52 \\
\hline 16 & Cypraea fimbriata & 127 & 20 & 13 & 160 \\
\hline 17 & Cypraea hirunda & 23 & 14 & 6 & 43 \\
\hline 18 & Cypraea isabella & 54 & 31 & - & 85 \\
\hline 19 & Cypraea milliaris & 41 & 21 & 10 & 72 \\
\hline 20 & Cypraea moneta* & 486 & 456 & 214 & 1156 \\
\hline 21 & Engina mendicuria & 127 & 20 & 13 & 160 \\
\hline 22 & Epitoniun perplexa & - & 6 & - & 6 \\
\hline 23 & Heliacus variegatus & - & 2 & - & 2 \\
\hline 24 & Helix aperta & 18 & 4 & - & 22 \\
\hline 25 & Mitra cucumerina & - & 1 & - & 1 \\
\hline 26 & Mitra floridula & - & - & 10 & 10 \\
\hline 27 & Mitra retusa & 69 & 54 & 25 & 148 \\
\hline 28 & Nassarius dorsatus & 259 & 174 & - & 433 \\
\hline 29 & Natica vitelellus & - & 12 & - & 12 \\
\hline 30 & Nerita albicilla & - & 171 & 97 & 701 \\
\hline 31 & Nerita plicata & - & 104 & 202 & 306 \\
\hline 32 & Pleuroploca filamentosa & - & - & 3 & 3 \\
\hline 33 & Pyrene testudinaria* & 1023 & 553 & 24 & 1600 \\
\hline 34 & Rhinoclavis bituberculata* & 275 & 218 & 313 & 806 \\
\hline 35 & Semicasis craticulum & - & 138 & 126 & 264 \\
\hline 36 & Srigatella litterata & - & - & 40 & 40 \\
\hline 37 & Strombus marginatus & - & - & 1 & 1 \\
\hline 38 & Strombus mutabilis & 71 & 50 & - & 121 \\
\hline 39 & Turbo argyrostamus & 70 & 57 & 7 & 134 \\
\hline \multirow[t]{2}{*}{40} & Turbo reevei & 31 & 5 & - & 36 \\
\hline & $\sum$ total individu & 4347 & 3592 & 1501 & 9440 \\
\hline
\end{tabular}

Keterangan : * Jenis dengan total jumlah individu dalam populasi $>500$ individu dalam 3 bulan. (Sumber: Sinulingga, 2004) 
Zahida dan Sinulingga

Tabel 2. Jumlah individu yang dipanen tiap jenis dengan pemisahan juvenil dan dewasa di Pantai Krakal Oktober-Desember 2003

\begin{tabular}{|c|c|c|c|c|c|c|c|c|c|c|c|}
\hline \multirow[b]{3}{*}{ No } & \multirow[b]{3}{*}{ Jenis } & \multicolumn{10}{|c|}{ Jumlah individu } \\
\hline & & \multicolumn{2}{|c|}{$\begin{array}{c}\text { Oktober } \\
2003 \\
\end{array}$} & \multicolumn{2}{|c|}{$\begin{array}{c}\text { November } \\
2003\end{array}$} & \multicolumn{2}{|c|}{$\begin{array}{c}\text { Desember } \\
2003\end{array}$} & \multicolumn{2}{|c|}{ Total } & \multicolumn{2}{|c|}{ Rerata 3 bulan } \\
\hline & & 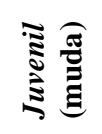 & 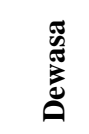 & 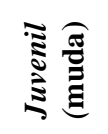 & 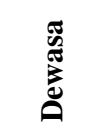 & 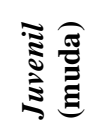 & $\begin{array}{l}\text { J } \\
\text { है } \\
\text { हैं } \\
0\end{array}$ & 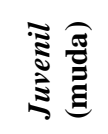 & 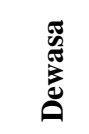 & 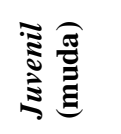 & 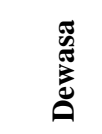 \\
\hline 1 & Argobuccinum pustulosum* & 181 & 160 & 162 & 104 & 39 & 38 & 382 & 302 & $127,3+$ & 100,6 \\
\hline 2 & Astrea phobia & - & - & - & - & 1 & 1 & 1 & 1 & $0,3=$ & 0,3 \\
\hline 3 & Bufonoria crumena & - & - & - & - & 43 & 40 & 43 & 40 & $14,3+$ & 13,3 \\
\hline 4 & Bursa granularis & - & - & - & - & 10 & 7 & 10 & 7 & $3,3+$ & 2,3 \\
\hline 5 & Cardinalia conus & - & - & - & - & 38 & 22 & 38 & 22 & $12,6+$ & 7,3 \\
\hline 6 & Clypeomorus traillii & 37 & 18 & 25 & 11 & - & - & 62 & 29 & $20,6+$ & 9,6 \\
\hline 7 & Conus ebraeus & 35 & 20 & 25 & 21 & 13 & 10 & 73 & 51 & $24,3+$ & 17 \\
\hline 8 & Conus capitaneus & 26 & 21 & 15 & 16 & - & - & 41 & 37 & $13,6+$ & 12,3 \\
\hline 9 & Conus lividus* & 127 & 124 & 129 & 87 & 128 & 80 & 384 & 288 & $128+$ & 96 \\
\hline 10 & Cypraea annettae* & 66 & 180 & 118 & 116 & 13 & 12 & 197 & 308 & $65,5-$ & 102,6 \\
\hline 11 & Cypraea annulus* & 111 & 93 & 118 & 116 & 43 & 23 & 272 & 232 & $90,6+$ & 75 \\
\hline 12 & Cypraea arabica & 89 & 76 & 60 & 48 & 5 & 4 & 154 & 128 & $51,3+$ & 42,6 \\
\hline 13 & Cypraea caput & 108 & 98 & 106 & 56 & 6 & 4 & 220 & 158 & $73,3+$ & 52,6 \\
\hline 14 & Cypraea corneola & 48 & 36 & 37 & 26 & 22 & 12 & 107 & 74 & $35,6+$ & 24,6 \\
\hline 15 & Cypraea erosa & 22 & 14 & 10 & 10 & - & - & 32 & 24 & $10,6+$ & 8 \\
\hline 16 & Cypraea fimbriata & 64 & 53 & 62 & 36 & 5 & 5 & 131 & 94 & $43.6+$ & 31,3 \\
\hline 17 & Cypraea hirunda & 12 & 11 & 9 & 5 & 4 & 2 & 25 & 18 & $8,3+$ & 6 \\
\hline 18 & Cypraea isabella & 33 & 21 & 18 & 13 & - & - & 51 & 34 & $17+$ & 11,3 \\
\hline 19 & Cypraea milliaris & 24 & 17 & 11 & 10 & 8 & 2 & 43 & 29 & $14,3+$ & 9,6 \\
\hline 20 & Cypraea moneta* & 251 & 235 & 325 & 131 & 136 & 78 & 712 & 444 & $237,3+$ & 148 \\
\hline 21 & Engina mendicuria & 64 & 63 & 13 & 7 & 7 & 6 & 84 & 76 & $28+$ & 25,3 \\
\hline 22 & Epitoniun perplexa & - & - & 3 & 3 & - & - & 3 & 3 & $1=$ & 1 \\
\hline 23 & Heliacus variegatus & - & - & 1 & 1 & - & - & 1 & 1 & $0,3=$ & 0,3 \\
\hline 24 & Helix aperta & 11 & 7 & 3 & 1 & - & - & 14 & 8 & $4,6+$ & 2,6 \\
\hline 25 & Mitra cucumerina & - & - & 0 & 1 & - & - & 0 & 1 & $0-$ & 0,3 \\
\hline 26 & Mitra floridula & - & - & - & - & 5 & 5 & 5 & 5 & $1,6=$ & 1,6 \\
\hline 27 & Mitra retusa & 40 & 29 & 33 & 21 & 17 & 8 & 90 & 58 & $30+$ & 19,3 \\
\hline 28 & Nassarius dorsatus & 142 & 117 & 94 & 80 & - & - & 236 & 197 & $78,6+$ & 65,6 \\
\hline 29 & Natica vitelellus & - & - & 7 & 5 & - & - & 7 & 5 & $2,3+$ & 1,6 \\
\hline 30 & Nerita albicilla & - & - & 96 & 75 & 63 & 34 & 159 & 109 & $53+$ & 36,3 \\
\hline 31 & Nerita plicata & - & - & 85 & 19 & 129 & 73 & 214 & 92 & $71,3+$ & 30,6 \\
\hline 32 & Pleuroploca filamentosa & - & - & - & - & 2 & 1 & 2 & 1 & $0,6+$ & 0,3 \\
\hline 33 & Pyrene testudinaria* & 532 & 491 & 532 & 21 & 13 & 11 & 1065 & 523 & $355+$ & 174,3 \\
\hline 34 & Rhinoclavis bituberculata* & 143 & 132 & 79 & 139 & 159 & 154 & 381 & 425 & $93,6-$ & 107,6 \\
\hline 35 & Semicasis craticulum & - & - & 75 & 63 & 70 & 56 & 145 & 119 & $48,3+$ & 39,6 \\
\hline 36 & Srigatella litterata & - & - & - & - & 30 & 10 & 30 & 10 & $10+$ & 3,3 \\
\hline 37 & Strombus marginatus & - & - & - & - & 0 & 1 & 0 & 1 & $0-$ & 0,3 \\
\hline 38 & Strombus mutabilis & 38 & 33 & 23 & 17 & - & - & 61 & 50 & $20,3+$ & 16,6 \\
\hline 39 & Turbo argyrostamus & 40 & 30 & 32 & 25 & 4 & 3 & 76 & 58 & $25,3+$ & 19,3 \\
\hline 40 & Turbo reevei & 16 & 15 & 3 & 2 & - & - & 19 & 17 & $6,3+$ & 5,6 \\
\hline \multirow{2}{*}{\multicolumn{2}{|c|}{$\begin{array}{l}\text { total individu tiap bulan } \\
\text { (juvenil, dewasa) }\end{array}$}} & 2260 & 2087 & 2309 & 1283 & 901 & 600 & \multirow{2}{*}{5470} & \multirow{2}{*}{3970} & \multirow{2}{*}{1823,6} & \multirow{2}{*}{1323,3} \\
\hline & & \multicolumn{2}{|c|}{4347} & & \multicolumn{2}{|c|}{1501} & & & & \\
\hline \multicolumn{2}{|c|}{$\sum$ total individu selama 3 bulan } & & & 9440 & & & & \multicolumn{2}{|c|}{9440} & \multicolumn{2}{|c|}{3146,69} \\
\hline
\end{tabular}

Keterangan: *: Jenis dengan total jumlah individu dalam 3 bulan $>500,+$ : jumlah juvenil lebih banyak dari dewasa, = jumlah juvenil sama dengan dewasa, - jumlah juvenil lebih sedikit dari dewasa (Sumber: Sinulingga, 2004). 


\section{Penurunan Populasi Siput dalam Tiga Bulan}

Tabel 1. menunjukkan bahwa 15 dari 17 jenis yang selalu didapatkan tiap bulan terjadi penurunan panenan. Lebih lanjut kecenderungan ini juga bisa dilihat pada Gambar 1. yang menunjukkan penurunan jumlah individu per bulan pada tujuh jenis utama yang ditemukan. Pyrene testudinaria mendominasi komunitas pada bulan Oktober, dan efek pemanenan terlihat dengan menurunnya jumlah individu dalam populasi di bulan November dan Desember 2003. Cypraea moneta yang jumlah individu dalam populasi tercatat pada urutan kedua setelah Pyrene menunjukkan populasi yang relatif konstan. Diduga kelimpahan yang tinggi dan umum didapat merupakan akibat dari reproduksi yang bisa dilakukan beberapa kali dalam setahun atau beberapa kali dalam satu musim. Hal ini didukung oleh Fretter dalam Tompa et al. (1984), yang menjelaskan bahwa musim reproduksi yang lama dapat merupakan akibat dari kelompok umur yang berbeda atau individu yang kawin pada waktu yang berbeda atau masing-masing betina meletakkan telur beberapa kali dalam setahun.

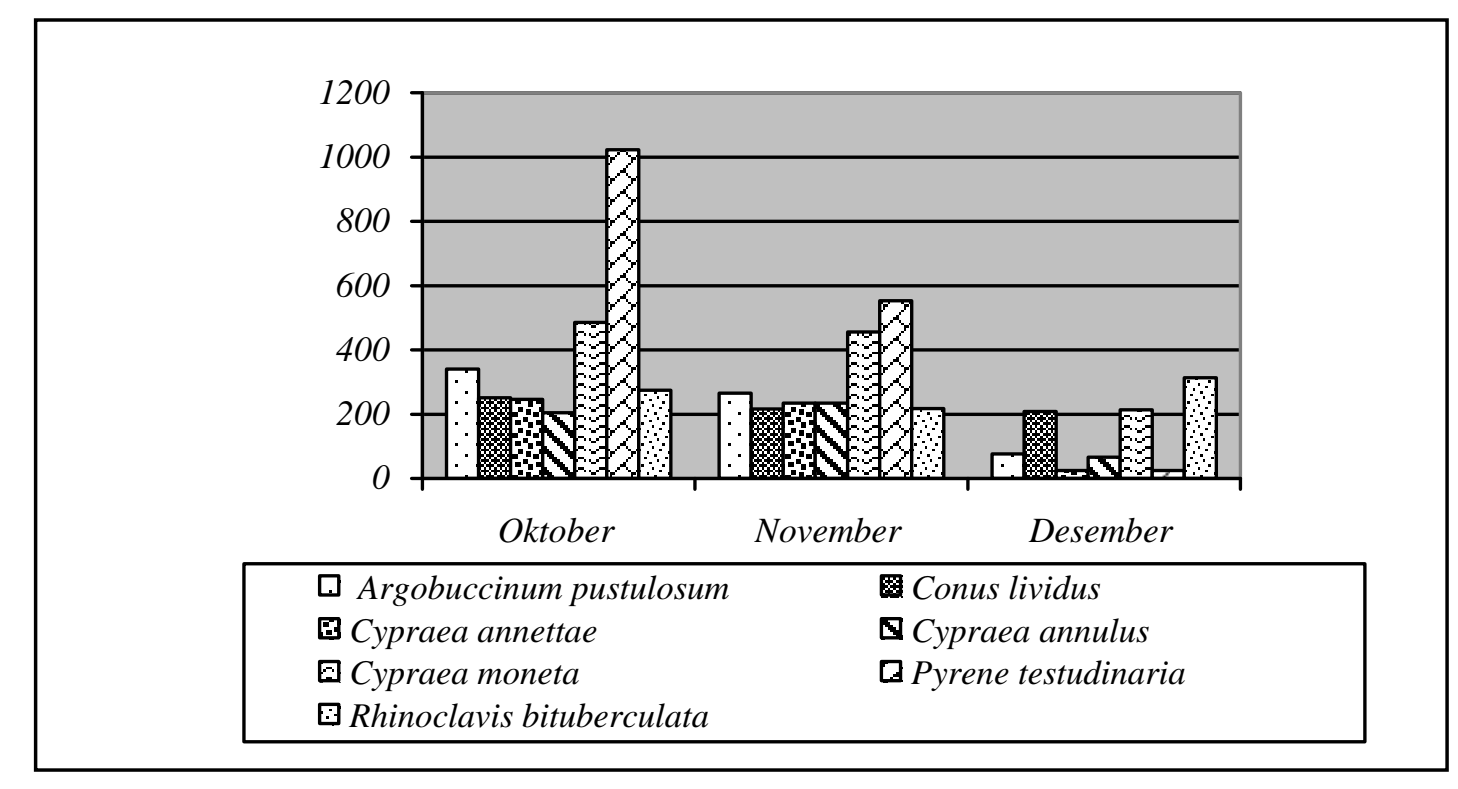

Gambar 1. Populasi hasil panenan tujuh jenis Gastropoda dengan jumlah individu total lebih dari $500(5 \%)$ yang tercatat pada bulan Oktober - Desember 2003

Analisis berikutnya dilakukan dengan pemisahan Gastropoda juvenil dan dewasa (Lihat Tabel 2). Data menunjukkan bahwa pada tiap jenis didapati ukuran panjang cangkang yang kontinyu, sehingga diperkirakan masing-masing jenis memiliki frekuensi reproduksi beberapa kali dalam satu tahun. Dasar pemisahan dilakukan dengan pendekatan ukuran yang dipisahkan oleh median masing-masing jenis, sehingga ukuran dibawah median diasumsikan sebagai individu juvenil dan ukuran di atas median diasumsikan individu dewasa. Data komposisi umur secara sederhana ini perlu dikembangkan agar nantinya dapat dilakukan justifikasi sementara keadaan pemanenan (telah mengalami tangkap lebih ataukah belum).

Menurut Primack (1998) dalam struktur populasi alami, apabila ditemukan individu juvenil dalam jumlah banyak menunjukkan bahwa populasi dalam kestabilan atau populasi sedang meningkat, namun bila individu dewasa lebih banyak berarti populasi sedang menurun. Artinya lima dari tujuh jenis utama menunjukkan populasi dalam kestabilan atau mengalami peningkatan. Rasio individu juvenil terhadap dewasa berturut-turut adalah Argobuccinum pustulosum $382: 302$, Conus 
lividus $384: 288$, Cypraea annulus $272: 232$, Cypraea moneta 712 : 444, dan Pyrene testudinaria $1065: 523$, sementara itu dua jenis sisanya adalah Cypraea annettae $197: 308$ dan Rhinoclavis bituberculata 381 : 425. Bila dilihat secara keseluruhan, maka 32 dari 40 jenis mengalami peningkatan. Namun dalam populasi hasil pemanenan justru jika jumlah dewasa sedikit maka dikatakan telah tangkap lebih (overfishing) (Sparre and Venema, 1998), artinya 32 dari 40 jenis telah mengalami tangkap lebih. Hal ini dapat dimengerti karena aktivitas pencarian atau pemanenan amat mengandalkan kejelian penglihatan untuk menemukan siput, sehingga individu dengan ukuran besar akan lebih mudah terlihat dibanding yang juvenil.

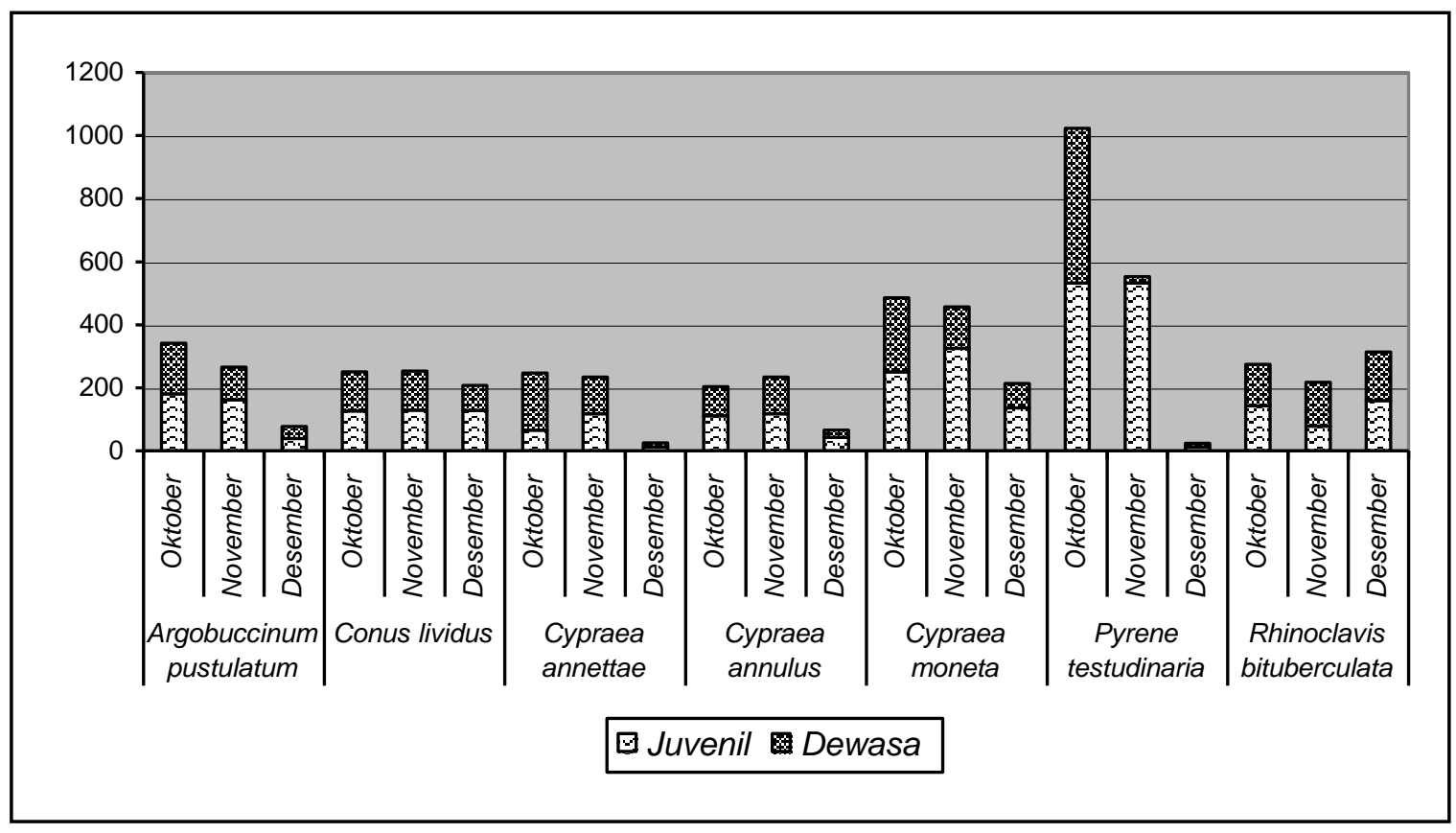

Gambar 2. Jumlah individu Gastropoda utama juvenil dan dewasa bulan Oktober -Desember 2003

Gambar 2. menunjukkan kecenderungan penurunan cacah individu dalam populasi panenan dari bulan ke bulan. Nampak bahwa hampir semua jenis mengalami penurunan. Jelas terlihat bahwa juvenil lebih mendominasi dibanding individu dewasa. Data penurunan populasi yang ada, meskipun baru berupa penelitian jangka pendek, bisa dikatakan cukup mengkhawatirkan. Sebagai perbandingan, dalam penelitian yang dilakukan di Costa Rica, densitas siput yang dibandingkan pada pantai tak tereksploitasi dengan pantai tereksploitasi, dapat menunjukkan bahwa pengurangan populasi bisa mencapai tiga kali lipat lebih rendah pada pantai tereksploitasi (Schmidt et al., 2002). Penelitian tersebut dilakukan pada jenis Cittarium pica yang merupakan
Gastropoda ranking kedua terbesar yang dipanen wilayah tersebut

Terlalu awal untuk dapat membuat kesimpulan status overfishing. Bagi keperluan tersebut masih diperlukan berbagai data tambahan yang harus diobservasi ataupun diteliti, seperti data pertumbuhan, maksimum pemanenan yang lestari dan sebagainya, dan masing-masing nilai akan khas bagi tiap jenis.

Telah dimungkinkan saat ini memperkirakan umur jenis-jenis siput (gastropoda). Pada bivalvia, telah dikenal metode untuk memperkirakan umur spesimen yaitu dengan melakukan penghitungan cincincincin pertumbuhan (external shell rings) analog dengan cincin pertumbuhan pada tumbuhan (Jones, 1989). Hal ini telah dilakukan oleh Peharda et al., (2002) pada 
Arca noae L., Aldridge (1999) pada lima jenis anggota familia Unionidae, dan Gaspar et al., (2004) pada Chamelea gallina, namun untuk gastropoda yang memiliki variasi morfologi luar tidak mudah untuk diterapkan. Contohnya tidak semua jenis memiliki cincin pertumbuhan seperti pada Cypraea, apalagi permukaan cangkangnya juga tidak bertekstur (glossy). Pada gastropoda perkiraan umur telah dilakukan dengan menggunakan persamaan pertumbuhan von Bertalanffy (Sparre and Venema, 1998) seperti telah dilakukan oleh Morton dan Chan (2004) pada Nassarius festivus, Caetano et al., (2003) pada Olivancillaria vesica vesica (Gmelin, 1791), Schmidt et al., (2002) pada Cittarium pica. Namun untuk perkiraan umur ini masih diperlukan beberapa data tambahan lain. Untuk akurasi data pendekatan perkiraan umur siput maupun kerang seringkali masih didukung oleh pendekatan cara lain seperti penggunaan mikrostruktur cangkang (acetate peels) (Gaspar et al., 2004) selain penghitungan cincin pertumbuhan dan length-frequency distribution analysis (Sparre and Venema, 1998). Perkiraan umur ini amat penting untuk memperkirakan rentang hidup, sehingga nantinya akan diketahui apakah spesimen yang telah dikoleksi dalam penelitian ini telah sungguh mencapai umur dewasa ataukah belum. Bisa jadi ukuran spesimen yang tersedia ini masih harus dikategorikan siput dewasa muda, yang pertumbuhannya masih bisa jauh lebih besar lagi. Bila memang demikian tentu ini merupakan kabar buruk, artinya jumlah telur yang mampu diproduksi belum maksimal selama ini, karena telah dipanen terlebih dahulu. Lebih lanjut, nilai ekonomi kelompok hewan yang relatif rendah, mengakibatkan kurangnya perhatian serta data-data pendukung dari khalayak peneliti.

\section{Kesimpulan}

Penelitian ini berhasil mengungkap beberapa temuan sebagai berikut:

Jenis siput yang dipanen di pantai Krakal sebanyak 40 jenis. Volume pemanenan perbulan sebesar kurang lebih 3146 individu dalam sekitar 28 jenis. Ukuran cangkang siput bervariasi secara kontinyu, dan ditemukan sejumlah 58\% jenis yang dipanen (32 dari 40 jenis) memiliki jumlah individu juvenil lebih banyak dibanding dewasa. Artinya diduga telah terjadi panen lebih, mengingat pemanenan didasarkan pada mudah tidaknya individu terlihat oleh pemanen.

\section{Ucapan Terima Kasih}

Penelitian ini dimungkinkan atas kerjasama yang baik dengan Mastok Bastanta Sinulinga sebagai asisten lapangan dan pendanaan dari Universitas Atma Jaya Yogyakarta melalui Fakultas Biologi dan Lembaga Penelitian Universitas.

\section{Daftar Pustaka}

Aldridge, D.C. 1999. The Morphology, Growth and Reproduction of Unionidae (Bivalvia) in a Fenland Waterway. Journal of Molluscan Studies. 65: 47-60

Caetano, C.H.S., Veloso, V.G. and Cardoso, R.S. 2003. Population Biology and Secondary Production of Olivancillaria vesica vesica (Gmelin, 1791) (Gastropoda:Olividae) on a Sandy Beach in Southeastern Brazil. Journal of Moluscan Studies 69: 67-73

Dharma, B. 1988. Siput dan Kerang Indonesia (Indonesian Shells). Jakarta: PT. Sarana Graha

Dharma, B. 1992. Siput dan Kerang Indonesia (Indonesian Shells II). Wiesbaden: Verlag Christa Hemmen.

Fretter, V. 1984. Prosobranchs. In A.S. Tompa, N.H. Verdonk and J.A.M. Biggelaar (Eds). The Mollusca. Vol 7: Reproduction. Academic Press, Inc. New York.

Gaspar, M.B., Pereira, A.M. Vasconcelos, P. and Monteiro, C.C. 2004. Age and Growth of Chamelea gallina from the Algarve Coast (Southern Portugal): Influence of Seawater Temperature and Gametogenic Cycle on Growth Rate. Journal of Molluscan Studies 70(4): 371-377

Jones, D.S. 1989. Growth Rings and Longevity in Bivalves. Conchologists of America. http://coa.acnatsci.org/conchnet/jones893.html. Download date: 29 Juni 2004 


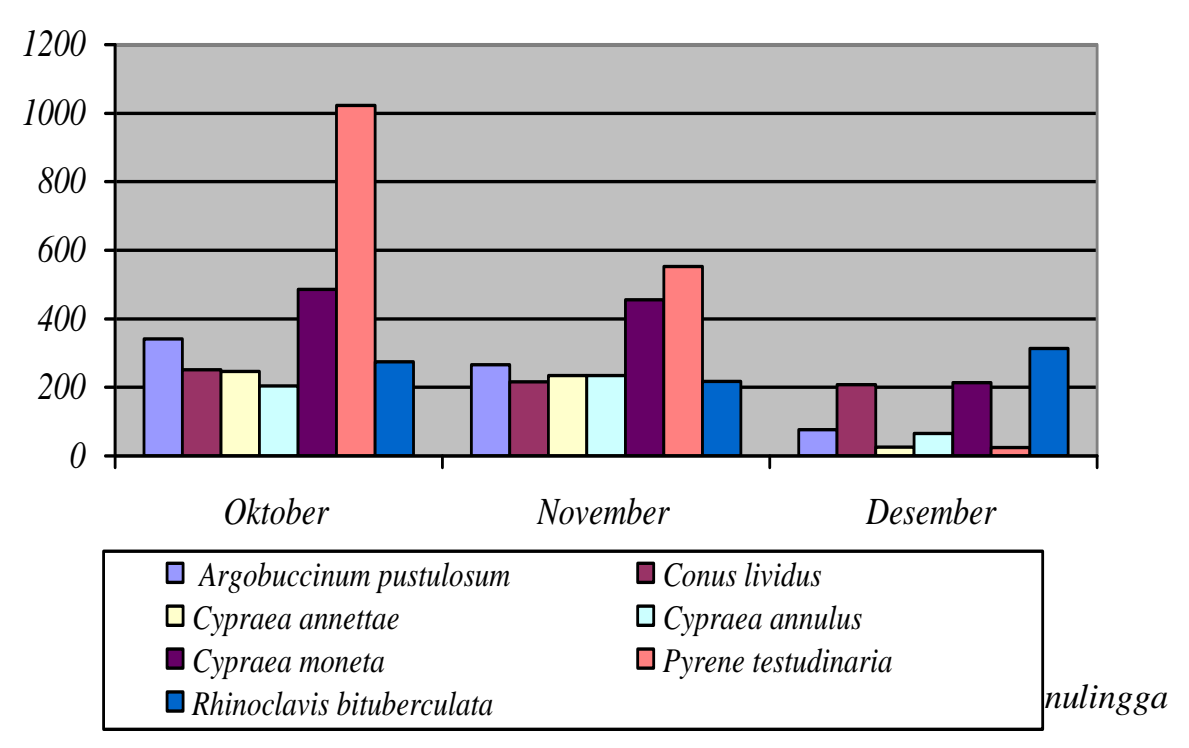

Morton, B. and Chan, K. 2004. The Population Dynamics of Nassarius festivus (Gastropoda: Nassariidae) on Three Environmentally Different Beaches in Hong Kong. Journal of Molluscan Studies. 70(4): 329-339.

Nawani, H. 1998. Metode Penelitian Sosial. Yogyakarta: Universitas Gadjah Mada Press

Oliver, A.P.H. 1989. The Hamlyn Guide to Shells of the World. London: The Hamlyn Publishing Group Limited.

Peharda, M., Richardson, C.A., Onofri, V., Bratos, A. and Crncevic, M. 2002. Age and Growth of the Bivalve Arca Noae L. in the Croatioan Adriatic Sea. Journal of Molluscan Studies. 68: 307-310

Primack, R.B., Supriatna, J., Indrawan, M. dan Kramadibrata, P. 1998. Biologi Konservasi. Yayasan Obor Indonesia, Jakarta.

Schmidt, S., Wolff, M. and Vargas, J.A. 2002. Population Ecology and Fishery of Cittarium pica (Gastropoda: Trochidae) on the Caribbean

Coast of Costa Rica. Rev. Biol. Trop. 50 (3/4): 1079-1090.

Severn, P.F., Severn, M. and Dyerly, R. 1998. Tropical Seashells. Periplus.

Sinulingga, M.B. 2004. Pemanenan Jenis Gastropoda di Pantai Krakal, Kabupaten Gunung Kidul, daerah Istimewa Yogyakarta. Skripsi. (tidak dipublikasikan). Fakultas Biologi. Universitas Atma Jaya Yogyakarta. Yogyakarta.

Sparre, P. and Venema, S.C. 1998. Introduction to Tropical Fish Stock Assessment. Part I. Manual FAO Fisheries Technical Paper. No. 306/1. Rev.2. FAO Corporate Document Repository. Rome. http://www.fao.org/documents/intro.asp. download date: 29 Juni 2004

Zahida, F. 2002. Peran Gastropoda dan Bivalvia dalam Masyarakat Indonesia. Berita Solaris 7 (1-2): 3 7. ISSN: $1410-5322$ 